\title{
Research on Enterprise Human Resources Management Mode Innovation in the Age of Big Data
}

\author{
Hongke Shen \\ Chengdu Neusoft University \\ Chengdu, China 611844
}

\begin{abstract}
With rapid development of internet and coming of the age of big data, great power and value contained in big data will lead to rapid increase of industry pioneering work and management reform. Traditional human resources management mode and work mode can not satisfy enterprises' practical need of human resources management any longer. Enterprise managers have to update concept and quicken forming of big data thinking, establish effective enterprise human resources management innovation system, adopt humanization, informatization and data management methods, establish a professional human resources management team and a human resources management information system, and take full advantage of information technology in the age of big data to serve enterprise human resources management work.
\end{abstract}

Keywords-big data; enterprise; human resources; innovation research

\section{INTRODUCTION}

With continuous development of domestic social economy, the age of big data has become the mainstream and trend of current world development. Information technology has permeated every aspect of social mass production and life, bringing a rough and direct challenge for domestic enterprise development. A great comprehensive social transformation of thinking has begun. The age of big data provides the foundation for another historic transformation of times. There is no doubt that transformation of the age of big data would be the key weapon for enterprises to speed up their pace of transformation. Only when enterprises have professional management experience and innovative capability, can they go further and further. Also, data analysis is an important skill of domestic enterprise human resources. In the age of big data, enterprise manager needs to take advantage of technical advantage of big data to strengthen optimization and innovation of enterprise human resources management and realize whole control over complete work of enterprise, thus achieving normal operation and profit of enterprise.

\section{RELATION BETWEEN RAPID DEVELOPMENT OF BIG DATA AND ENTERPRISE HUMAN RESOURCES MANAGEMENT MODE INNOVATION}

\section{A. Achieve Transparency, Persuasiveness and Universality of Data and Manpower Management Resource}

With the age of big data as its background, the world becomes transparent and open. Many domestic and foreign manufacturers use advanced technology to process and integrate important data of valued clients and suppliers. They can make better use of transparency and universality of the age of big data in many aspects, thus obtaining various kinds of inspiration and key hints concerning product design and quantity production of product. Various kinds of product manufacturing all over the world, especially advanced manufacturing industry with automobile industry as its representative, gradually collaborates and exchanges even in the step of production design, and takes full advantage of pervasiveness and universality of data and resource to make the whole industry chain more complete, thus making it more convenient to contact and communicate with partners.

\section{B. Achieve Influence on Enterprise's Internal Decision- Making and Planning and External Competition Mode}

In the age of big data, resource and data have great influence on enterprise's decision-making and competition. It is necessary to use controllability and specifity of relevant data and material, set up relevant hypothesis, analysis and verification model of enterprise, make preparation and layout for relevant internal decision of enterprise, and carry out real-time supervision and rectification. In the meantime, enterprises can actively use extensive client information and data to analyze and understand the whole competitive market according to their actual development situation. By doing so, they can accurately locate different clients and adjust individualized strategy, thus having great significance for enterprises to open up a new prospect and unfold powerful competition in domestic market.

\section{Achieve Reform and Transformation of Enterprise Human Resources Management Work Mode}

Advanced technology and exquisite arithmetic method brought by the age of big data play an important role in enterprise's implementation of innovation and reform of 
human resources management mode. With the help of advanced computer analysis and process function and exquisite and accurate arithmetic algorithm, enterprises can realize cascade and communication between their own production line and the whole sales section, use sensor technology of data to build up automatic regulating system of enterprise's production and sales process and put excess human resources and financial and material resources into design and production processes of products, thus further realizing reform and transformation of enterprise human resources management mode and providing enterprises with more chances to realize self-transcendence, achieve higher output criteria and optimize profit.

\section{Achieve Establishment of Business Model in Enterprise Human Resources Management Work}

Constant improvement of level of informatization will definitely give rise to ups and downs in the whole market. Push of the age of big data provides solid foundation for establishment of new high-tech business model. Most of the new enterprise types are systematic business models based on information and data. Market transaction and production and sales become the most important part of new business model system work. Management and operation of enterprises play the role of an intermediary, and their significance to the whole value chain is mainly manifested in transmission and management of data instead of previous unilateral control. Further development of society and technology will definitely facilitate improvement of new business models to create more valuable practical discharge data.

\section{FUNCTION AND MEANING OF RAPID DEVELOPMENT OF BIG DATA TO ENTERPRISE HUMAN RESOURCES MANAGEMENT MODE INNOVATION}

\section{A. Fully Realize Transformation of Inner-Enterprise Human Resources Manager's Operation and Management Concept}

The coming and rapid development of the age of big data brings great challenges and requirements to enterprise's manager. In order to further use big data to improve and perfect enterprise human resources management work, managers of enterprise have to transform and adjust their own operation and management concept. First, managers have to adapt to the tendency that the age of big data has already come. According to requirement of openness and transparency of big data age, they have to set up open and active management concept and embrace every challenge passionately. Second, closely band the inner-enterprise human resources management work and advanced technology and resources of big data age together. Pay attention to integration and adoption of various types of data relevant to their own enterprises. Change the limitation of singly carrying out human resources management work previously. Pay abundant attention to enterprise employee using big data training platform to make academic improvement and cooperate and communicate, and apply big data thought and guideline to the whole process of enterprise development in an even better fashion, including every link of enterprise's strategy making, personnel recruitment, performance evaluation and employee compensation.

\section{B. Realize Innovation of Inner-Enterprise Information- Based and Technology-Based Human Resources Management Mode and Method}

Information-based management mode and method is another requirement for enterprise development in the age of big data. Enterprises should care for employee, play attention to employee's spiritual and material needs, and provide development platform of the same value and condition for all employees. Combine employee's need and development with enterprise's development and improvement in an even better fashion through establishing equal data management model of enterprise, manager and employee. You can also take advantage of advanced and convenient internet technology to establish and perfect inner-enterprise human resources management system and mechanism. Make the whole enterprise's staff management correspond to information-based database. Fully perfect work flow of enterprise's human resources management. Compare human resources information statistical analysis with enterprise's strategic target to make more reliable decisions, thus making information-based and technology-based human resources management model and method provide fundamental services for development and progress of the whole enterprise.

\section{INNOVATION MANNER AND METHOD OF ENTERPRISE Human Resources MANAGEMENT Mode IN THE AGE OF BIG DATA}

\section{A. Use Rich Resources in the Age of Big Data to Hunt for Excellent Job Seekers in Society}

Today, the most widespread and simplest job hunting manner in foreign and domestic talent market and job market is submitting resume on the internet and waiting for answers and notifications from recruiters. Social environment in the age of big data quickens development pace of internet technology. Countless information of job seekers appears on the internet, and there is no lack of excellent talents. Through display and analysis of various kinds of internet data, enterprises can obtain important resources like personality characteristics, professional competence and skilled field from job-seeking information of job seekers. Match enterprise's demand standard with excellent job seeker's jobseeking demand through popular search engine, examine and choose matching degree, analyze data and rank job hunting, thus making corresponding radar analysis chart. Cooperate with recruiters of enterprise human resources management department and finally select out job seekers who are most suitable for enterprise development, thus saving more manpower and material resources, providing social job seekers with more fair opportunities and further promoting innovation and reform of enterprise human resources management mode. 


\section{B. Establish Advanced System and Mechanism of Human Resources Management Work in the Age of Big Data}

From macro perspective, inner-enterprise human resources management work has relative precision and guidance towards enterprise's whole development. From micro perspective, inner-enterprise human resources management work conducts single management and supervision over enterprise's inner personnel, and job direction and work ability of staff. For both perspectives, enterprises need to establish advanced management system and mechanism as important foundation of carrying out inner human resources management work with social and economic background of the age of big data. Enterprises have to adapt to environment of the age of big data as a premise, and improve their career objective and development strategy according to their practical development. Besides, enterprises need to make strategic objectives corresponding to development planning. Establish human resources management work department as the core integrated management system and mechanism of the whole enterprise to set standard for relevant human resources management system and get strict with assessment and examination of human resources management work, thus further promoting innovation and reform of enterprise human resources management work mode.

\section{Use Advanced Technology of the Age of Big Data to Realize Training and Learning of Staff}

The measure and research originate from MOOC of American education industry in 2013, which is a kind of online open course. Meanwhile, many foreign and domestic science and technology researchers and investment enterprises transfer their attention to this kind of advanced intelligent training and learning platform in succession. The technology has cross time significance for world's science, technology and knowledge development in a long time. Taking Tsinghua University and Peking University as representative, many famous domestic universities join the world competition successively. Enterprises need to further improve this kind of management training mode. Expand and develop online training by the way of collective learning or separate class. Put learning and training of inner-enterprise human resources management department into online platform. Favorable and active training and learning can give employee more confidence and passion in work. Enterprise can not only achieve good benefit of human resources management work, but also save a large part of training cost to get better enterprise construction and optimize profit.

\section{Build Enterprise's Own Professional and Strong Human Resources Management Team}

The most important feature of the age of big data is professional and advanced. In order to realize perfect transformation and stand out in fierce international competition, domestic enterprises have to adopt the most advanced and professional human resources management mode to conduct innovation and reform of enterprises themselves. A professional and strong human resources management team is the first step for enterprise to achieve professionalism and be unique. First, enterprises need to improve management skill and professional quality of inner management department staff. Apart from possessing basic qualification and ability of the job, staff members need to master advanced internet technology of the big data age and apply it to enterprise's human resources management work. Second, inner-enterprise human resources management department needs to have rigorous and serious work style and active and passionate innovation thought. Only when employee and manager are both professional and developmental, can enterprises develop their own feature in an even better fashion, realize self-transcendence and achieve more substantial and reliable development and progress.

\section{E. Use Information in the Age of Big Data to Conduct Examination and Ratification of Employee Decision}

Simplify whole enterprise's business and project flow through analysis and statistics of big data mode and save more manpower and material resources. Regard management work of human resources as a part of statistics to analyze and research on. For example, in employee decision making and demanded examination and ratification work, enterprise's human resources manager can develop strategies of hiring staff through display of data, including arrangement of staff salary, distribution of position, leaving office, reinstatement etc. Detailed statistics and classification of all these can be completed through data model, thus excluding large deviation and favoritism and irregularities fundamentally and ensuring that every employee's positioning and decision can be examined and ratified strictly and fairly.

\section{F. Use Excellent Information Technology in the Age of Big Data to Realize Supervision and Management of Employee}

Strategy research without practice as its foundation is idle theorizing. In order to fully use advanced technology in the age of big data to improve and perfect human resources management work, enterprises have to develop appropriate management policy according to their practical situation and constantly adjust and innovate in practice to make efficient management achievement. Data analysis and resource integration function in the age of big data can be well used in enterprise human resources management work. Enterprises can set up a staff database and integrate employee's checking-in, work performance, quarter performance and interpersonal relationship into a data package. Set up a data package for each employee. Regularly integrate and examine data package of superior and subordinate according to different departments and layers to ensure authenticity and reliability, thus connecting employee performance with human resources managers through display of data to realize mutual supervision and effective management inside the enterprise.

\section{CONCLUSION}

The age of big data is one of the most important signs of world development. Advanced technology of the age of big data gradually becomes domestic enterprise's most precious 
intangible assets and brand new reform factor and it is one important opportunity for domestic enterprise to realize business and management reform. Only by constantly speeding up concept innovation and practical reform of enterprise human resources management work and promoting further development of enterprise's strategic human resources management work, can the ability and experience in management policy and supervision system of enterprise human resources management be improved continuously, thus further promoting transformation and upgrade of enterprise human resources management mode and organizational structure and making innovation and reform of enterprise human resources management mode in the age of big data an irreplaceable wise choice.

\section{REFERENCES}

[1] He Yun, An Xing and Xue Jing. Reflection on Enterprise Human Resources Management Reform in the Age of Big Data [J]. Economic Research Reference, 2014,63:26-32.

[2] Zhang Xiaoxin and Li Lei. New Research on Enterprise Human Resources Management Mode Innovation in the Age of Big Data [J]. Operation Managers, 2015,02:205-206.

[3] Wang Qun and Zhu Xiaoying. New Reflection on Enterprise Human Resources Management Innovation in the Age of Big Data [J].Shenyang University of Technology Journal (Social Science Edition), 2015,03:255-259

[4] Chen Liyue. Research on New Mode of Human Resources Management Innovation in the Age of Big Data [J]. Modern Trade Industry, 2014,17:24-25. 